\title{
Physiological and clinical outcomes associated with use of one-way speaking valves in tracheostomised patients: a systematic review
}

\begin{abstract}
Background: The one-way speaking valve was first engineered in 1985 to allow patients with tracheostomy tubes to communicate. The research has indicated alternative physiological benefits of using a speaking valve, however this literature has not yet been evaluated. The purpose of this systematic review is to evaluate the evidence for the one-way speaking valve in relation to a range of physiological and clinical domains including vital signs, aspiration, olfaction, ventilation and tracheostomy weaning, hospital length of stay, and quality of life.

Methods: A literature search was conducted in September 2017. Studies were eligible if they compared the use of a one-way speaking valve to no speaking valve in tracheostomised patients, across various physiological or clinical parameters.

Results: Sixteen eligible studies were included in this review. A meta-analysis random-effect model $\left(I^{2}=71.96, p=0.006\right)$ found reduced instances of aspiration when a speaking valve was in situ compared to no speaking valve in situ (OR 0.122; $95 \%$ confidence interval, $0.031-0.479 ; P=0.003$ ). Statistically significant results were also found for the use of a one-way speaking valve in terms of olfaction, secretion management and ventilation.
\end{abstract}

Conclusion: There is emerging evidence for the additional benefits of using one-way speaking valves in patients with tracheostomy tubes. Further studies are required to investigate these other promising utilities of the speaking valve and the subsequent effects on reducing healthcare costs and improving patient outcomes.

Keywords: speaking valve; tracheostomy; aspiration; one-way valve; swallowing; communication 


\section{Physiological and clinical outcomes associated with use of one-way speaking valves in tracheostomised patients: a systematic review}

\section{Introduction}

A tracheostomy tube is an artificial airway inserted into the trachea to allow a more direct access for ventilation [1]. This is most commonly indicated for patients in the critical care setting who are anticipated to require prolonged mechanical ventilation [2]. Tracheostomy tubes have been shown to have a negative impact on physiological functions including swallowing, secretions clearance, and olfaction. Moreover, the presence of a tracheostomy tube can inhibit the production of speech and the patient's ability to communicate [3].

In 1985, a tracheostomised and ventilator dependent patient, David Muir, invented the Passy-Muir Valve [4]. This one-way valve designed to enable speech in patients with tracheostomy tubes (now commonly referred to as a "speaking valve") is routinely used in intensive care units (ICUs) worldwide. Whilst the majority of literature relating to the use of speaking valves have focused on the benefits of speech, there have been a small number of studies that have reported additional physiological and clinical benefits. The use of a speaking valve in tracheostomised patients has been demonstrated to restore normal subglottic air pressures, a key component of swallowing, thereby potentially improving swallow function and reducing the risk of aspiration [5]. Additionally, speaking valve may expedite weaning from mechanical ventilation [6] by creating a "no leak" system that re-establishes physiological positive end-expiratory pressure (PEEP), thus allowing patients to become accustomed to normal expiratory airflow patterns [4]. It has been suggested that the restoration of physiological PEEP may facilitate weaning by improving arterial oxygenation [7]. In addition, secretion management may also be enhanced with the use of a speaking valve by enabling a stronger, more effective cough and oral expectoration of secretions [4].

The purpose of this systematic review is to evaluate the evidence for the additional physiological and clinical benefits of using a one-way speaking valves in tracheostomised patients including swallowing and aspiration, physiological measures (including heart rate, blood pressure, and oxygen and carbon dioxide levels), olfaction, ventilator and tracheostomy weaning, ventilation, ICU and hospital length of stay, and quality of life. This review is registered with the International Prospective Register of Systematic Reviews (Registration Number: CRD42015028075).

\section{Methods}

\section{Paper Identification and Selection}

A systematic review was conducted of all published clinical studies that compared the use of a oneway speaking valve to no speaking valve for a range of physiological and clinical parameters in adult and paediatric patients (table 1). Studies were excluded if patients had laryngectomies or similar head and neck surgeries where the vocal cords were no longer engaged. The outcomes measures in the literature were analysed, which included swallowing and aspiration, physiological measures (including heart rate, blood pressure, and oxygen and carbon dioxide levels), olfaction, ventilation, hospital length of stay, quality of life, and ventilator and tracheostomy weaning.

A literature search was conducted in September 2017 using the MEDLINE, CINAHL, PubMed and Cochrane Library databases and the key words "one way speaking valve" OR "passy muir valve", and restricted to those studies published in English language. A supplementary search was conducted in May 2018, which revealed no new articles. Due to the limited number of studies, all articles were accepted if the date of publication was after the development of the Passy-Muir Valve in 1985. Articles were excluded based on the criteria outlined in the table 1. 


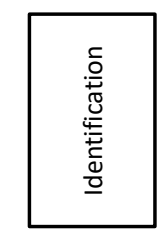

Papers imported through

MEDLINE, CINAHL, PubMed

\& Cochrane Library $(n=183)$
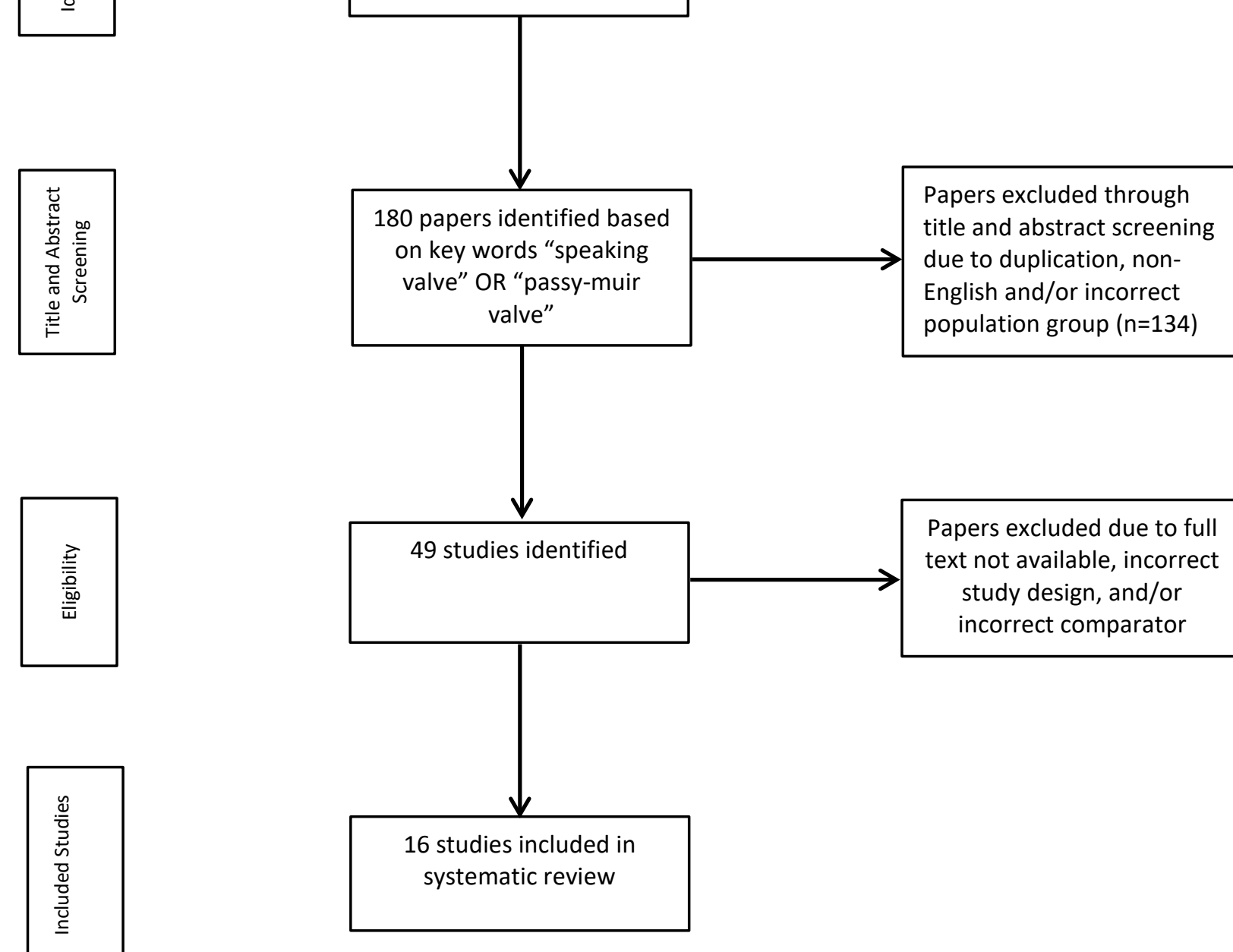

Papers excluded due to full text not available, incorrect study design, and/or incorrect comparator

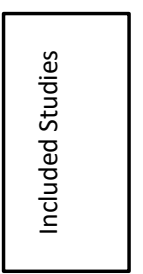

6 studies included in systematic review

Figure 1: Flow diagram of included papers

Table 1: Inclusion \& Exclusion Criteria

\begin{tabular}{lll}
\hline & Inclusion Criteria & Exclusion Criteria \\
\hline Design & $\begin{array}{l}\text { Clinical studies (including prospective } \\
\text { randomized controlled studies, clinical } \\
\text { case studies \& cohort studies) }\end{array}$ & $\begin{array}{l}\text { Single case studies } \\
\text { Expert opinions/consensus } \\
\text { Narrative/didactic reports } \\
\text { Conference Abstracts }\end{array}$ \\
\hline Participants & Adults and paediatric populations & $\begin{array}{l}\text { Laryngectomies or similar head and neck } \\
\text { surgeries where the vocal cords were no } \\
\text { longer engaged }\end{array}$ \\
\hline Comparison & Use of one way speaking valve & \\
& compared with no speaking valve & \\
\hline Outcome Measures & Swallowing/Aspiration & \\
& Oxygenation & \\
& Heart Rate & \\
& Olfaction & \\
Blood Pressure & \\
& Ventilator/Tracheostomy Weaning \\
& Length of Stay & \\
\hline
\end{tabular}


The online program 'Covidence' (www.covidence.org) was used throughout the screening process of this review. Two investigators (LO'C \& JP) screened studies individually for eligibility based on the inclusion and exclusion criteria outlined in table 1. A third investigator (NM) provided consensus if the initial two investigators were unable to reach an agreement regarding inclusion/exclusion of studies. Figure 1 outlines the reasons for excluding studies from this review, which included incorrect study design, different comparators or ineligible patient groups.

\section{Risk of Bias (Quality Assessment)}

The 20 question Institute of Health Economics (IHE) Quality Appraisal Checklist [8] was used to assess risk of bias across the domains of: study objective, design, population, intervention and cointervention, outcome measures, statistical analysis, results and conclusion, and competing interests and support. This checklist was validated [9] and documented as suitable in the quality assessment of case-series studies [9].

\section{Data Extraction and Analysis}

Both investigators ( $L O^{\prime} C$ \& JP) collected information on the following data: study design, total length of study, sequence generation, allocation sequence concealment, blinding, participant number, setting, diagnosis, age, sex, country, co-morbidity, number of intervention groups, details of the intervention, outcomes measured and recorded, time points measured and recorded, definition of outcomes and unit of measurement, number of participants in intervention/control group, sample size for each outcome, loss to follow-up, summary data for each intervention, estimate of effect (confidence interval/p value), funding source, and key conclusions of authors. The extracted data were coded with the initials of the individual investigator and compared as part of the analysis. If there were any discrepancies in data extraction, the third investigator (NM) provided arbitration.

\section{Results}

The original search identified 180 articles; however, 134 were excluded on title and abstract review due to duplications, non-English language, and/or incorrect population groups. The 46 remaining studies were reviewed and excluded if they did not meet the inclusion and exclusion criteria for the study design, and/or the comparison outlined in table 1. During eligibility screening, a further 32 articles were excluded, with 16 remaining studies included in this review, largely prospective casecontrolled and observational studies $(n=15)$ and one retrospective audit (figure 1 ).

\section{Demographics and setting}

Specific details for comparative studies are shown in table 2. Both adult and paediatric studies were included in the review, as well as research undertaken in a variety of clinical settings, from large teaching hospitals to community and outpatient settings. Paediatric studies were those with participants younger than 18 years of age. Participants ranged from 3 months to 89 years, with the mean age of 2.4 years for the paediatric studies, and 58.5 years for the adult studies. Both ventilator-dependent and spontaneously ventilating patients were included in the review, in addition to a range of diagnoses and length of time with tracheostomy.

\section{Appraisal of Evidence}

\section{Study Quality and Design}

All included studies compared physiological and clinical parameters with and without a speaking valve. The majority of studies $(n=15)$ were prospective designs, with one study [10] being a retrospective audit. 
The demographics of the literature evaluated is outlined in table 2 , and the main findings and results outlined in table 3 . A forest plot (figure 2 ) is also included in the results below.

Due to the low number of studies $(n=16)$ and heterogeneity in outcomes measures, a meta-analysis was only possible to evaluate the instances of aspiration. Comprehensive Meta-analysis software was used [11]. To compare the results between these trials, the dichotomous outcomes were expressed as odds ratio (OR) with $95 \%$ confidence intervals. The data were pooled using the fixedeffects model; however, when heterogeneity was statistically significant ( $Q$ statistic $P<0.01$ ), the data were reanalyzed using the random-effects model. Table 3 outlines the results from included studies in a descriptive fashion.

\section{Aspiration}

Eight studies [12-19] included aspiration as an outcome measure, with 5 of those studies able to be analysed in a meta-analysis $[12-15,20]$. A random-effect model $\left(I^{2}=71.96, p=0.006\right)$ found reduced instances of aspiration with a speaking valve in situ, compared to without a speaking valve in situ (OR 0.122; 95\% confidence interval, 0.031-0.479; $P=0.003$ ) (figure 2). Seven studies found that the use of a speaking valves reduced instances of aspiration, although this was only statistically significant in 5 of the studies. Caution should be applied to the results of the meta-analysis due to the inconsistencies of the study protocols including the use of thin, thick and pureed foods for the swallowing assessment. This is reflected in the results in figure 2.

Study name

$\begin{array}{lccccc} & \begin{array}{c}\text { Odds } \\ \text { ratio }\end{array} & \begin{array}{c}\text { Lower } \\ \text { limit }\end{array} & \begin{array}{c}\text { Upper } \\ \text { limit }\end{array} & \text { Z-Value } & \text { p-Value } \\ \text { Dettelback et al 1995 } & 0.003 & 0.000 & 0.056 & -3.867 & 0.000 \\ \text { Suiter et al 2003 } & 0.134 & 0.057 & 0.317 & -4.588 & 0.000 \\ \text { Epern et al 2000 } & 0.179 & 0.047 & 0.683 & -2.517 & 0.012 \\ \text { Srinet et al 2015 } & 1.000 & 0.239 & 4.184 & 0.000 & 1.000 \\ \text { Leder 1999 } & 0.044 & 0.002 & 0.834 & -2.081 & 0.037 \\ & 0.122 & 0.031 & 0.479 & -3.017 & 0.003\end{array}$

Odds ratio and $95 \% \mathrm{Cl}$

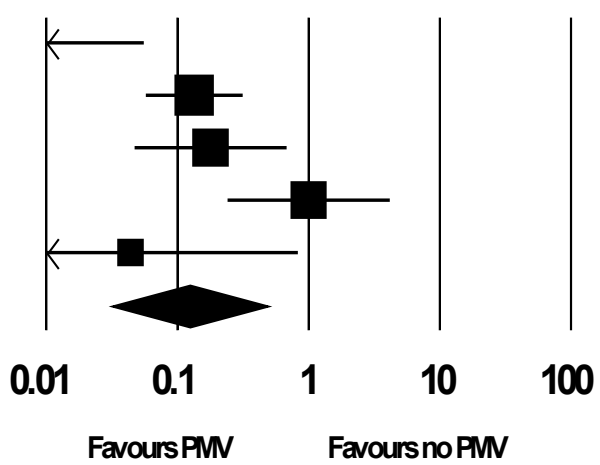

Figure 2: Instances of Aspiration with and without one-way speaking valve

\section{Physiological Measures}

Physiological measurements related to using a speaking valve were reported by five studies [3, 2124]. Outcome measures included heart rate (HR), respiratory rate (RR), oxygen saturations $\left(\mathrm{S}_{\mathrm{p}} \mathrm{O}_{2}\right)$, partial pressure of oxygen $\left(\mathrm{PaO}_{\mathrm{a}}\right)$, end tidal carbon dioxide $\left(\mathrm{EtCO}_{2}\right)$, and partial pressure of carbon dioxide $\left(\mathrm{P}_{\mathrm{a}} \mathrm{CO}_{2}\right)$. For the majority of studies, there was no statistically significant difference reported with any physiological measures, except for a statistically significant decrease in $\mathrm{EtCO}_{2}$ when using a speaking valve [24]. Two participants recorded a large decrease in their HR with use of speaking valves (100 vs 10 beats. $\mathrm{min}^{-1}$, and 89 vs 32 beats. $\mathrm{min}^{-1}$ ) [22], although this significant change was not reported in their study and not documented as an adverse event. No studies reported adverse events with use of speaking valves, and only one participant reported intolerance of the speaking valve, necessitating its removal [22]. 


\section{Olfaction}

Changes in olfaction with use of speaking valves was investigated in three studies [3, 22, 23]. The first study [22] looked at whether participants had a regained a sense of smell whilst using the speaking valve, and found that at 1 week after using the speaking valve, $80 \%$ of participants regained a sense of smell. Subjective improvements in olfaction [23], and statistically significant improvements in olfaction accuracy [25] were also reported.

\section{Secretion Management}

Secretion management, including 24-hour secretion accumulation [3] and number of tracheal suctions required $[22,23]$ with and without a speaking valve, were investigated in three studies. The first study [25] demonstrated a statistically significant reduction in secretion accumulation with speaking valve in situ. Similarly, it was subjectively reported that there was a decreased need for suctioning when the speaking valve was in situ [22, 23].

\section{Weaning}

Weaning from mechanical ventilation was investigated in two studies [10, 26]. The first study [10] conducted a retrospective audit following the implementation of a speaking valve, and found that the use of a speaking valve did not negatively impact the duration of mechanical ventilation time. The use of speaking valves was also found to shorten the length of mechanical ventilation by a median of 1 day [26], though this was not statistically significant. In addition to weaning from mechanical ventilation, weaning of the tracheostomy tube was also improved with use of speaking valves by a median time of 1 day, but again was not statistically significant [26].

\section{Ventilation}

Resting ventilation was investigated in two studies [24, 27] using measurements of end-expiratory lung impedance (EELI) to indicate changes in ventilation. EELI was measured by means of electrical impedance tomography (EIT), with an increase in EELI indicating an increase, or recruitment of alveolar units. In the first study [24], the results demonstrated significant increases in EELI, of up to $120 \%$ from baseline, during 30 minutes of quiet breathing, while using a speaking valve. The second study [27], used a data analysis tool (EIT Data Analysis 6.1) to investigate ventilation distribution. This study demonstrated a uniform increase in ventilation across all lung segments, indicating that hyperinflation was not occurring.

\section{ICU and Hospital Length of Stay}

Length of ICU and hospital stay following the implementation of speaking valves was only investigated in one study. This study showed no statistical difference in either hospital or ICU length of stay with the use of a speaking valve [26].

\section{Quality of Life}

The Visual Analog Self Esteem Scale (VASES) for communication quality of life, and the EuroQol-5D questionnaire (EQ-5D) for general health status was used to examine quality of life [26]. Whilst seven out of eight domains of the VASES and the mean difference in EQ-5D scores favoured the use of a speaking valve, these results were again not statistically significant [26]. 
Table 2: Study Design and Demographics

\begin{tabular}{|c|c|c|c|c|c|c|}
\hline Authors & Study Design & Study Overview & $\begin{array}{l}\text { Participant } \\
\text { Characteristics }\end{array}$ & Research Setting & Inclusion/ Exclusion Criteria & Outcome Measures \\
\hline $\begin{array}{l}\text { Barraza et al. } \\
(2014)^{[21]}\end{array}$ & $\begin{array}{l}\text { Prospective } \\
\text { Case-control } \\
\text { Study }\end{array}$ & $\begin{array}{l}\text { To evaluate the safety of SV } \\
\text { overnight while sleeping }\end{array}$ & $\begin{array}{l}\mathrm{n}=9 \\
2-11 \text { years } \\
\text { Mean age: } 5.6 \mathrm{yrs}\end{array}$ & $\begin{array}{l}\text { Paediatric Inpatient } \\
\text { Setting }\end{array}$ & $\begin{array}{l}\text { Inclusion: Tracheostomy }>48 \mathrm{hrs,} \mathrm{patent} \mathrm{upper} \mathrm{airway,} \mathrm{alert} \\
\text { and responsive, no acute respiratory tract infection }\end{array}$ & RR; HR; SpO2; EtCO2; \\
\hline $\begin{array}{l}\text { Dettelbach et } \\
\text { al. }(1995)^{[12]}\end{array}$ & $\begin{array}{l}\text { Prospective } \\
\text { Descriptive } \\
\text { Study }\end{array}$ & $\begin{array}{l}\text { To assess the benefits of } S V \text { in } \\
\text { decreasing aspiration }\end{array}$ & $\begin{array}{l}\mathrm{n}=11 \\
43-85 \text { years } \\
\text { Mean age: } 65.9 \mathrm{yrs}\end{array}$ & $\begin{array}{l}\text { Adult Inpatient } \\
\text { Setting }\end{array}$ & $\begin{array}{l}\text { Inclusion: partial laryngectomies, laryngeal innervation } \\
\text { defects, central neurological disease } \\
\text { Exclusion: no evidence of aspiration, not a candidate for } \\
\text { modified barium swallow }\end{array}$ & $\begin{array}{l}\text { Aspiration of thin, thick and pureed } \\
\text { consistencies (VFSS) }\end{array}$ \\
\hline $\begin{array}{l}\text { Elpern et al. } \\
(2000)^{[14]}\end{array}$ & $\begin{array}{l}\text { Prospective } \\
\text { Descriptive } \\
\text { Study }\end{array}$ & $\begin{array}{l}\text { To assess the benefits of } \mathrm{SV} \text { in } \\
\text { decreasing aspiration }\end{array}$ & $\begin{array}{l}\mathrm{n}=15 \\
32-84 \text { years } \\
\text { Mean age: } 60.0 \mathrm{yrs}\end{array}$ & $\begin{array}{l}\text { Multi-center study, } \\
\text { two acute care } \\
\text { hospitals, one } \\
\text { rehabilitation } \\
\text { hospital } \\
\end{array}$ & $\begin{array}{l}\text { Inclusion: } \geq 18 \text { years } \\
\text { Exclusion: need for mechanical ventilation, inability to } \\
\text { tolerate cuff deflation, compromised upper airway patency }\end{array}$ & Aspiration of thin liquid (VFSS) \\
\hline $\begin{array}{l}\text { Freeman- } \\
\text { Sanderson et al. } \\
(2016)^{[26]}\end{array}$ & $\begin{array}{l}\text { Prospective } \\
\text { Randomized } \\
\text { clinical trial }\end{array}$ & $\begin{array}{l}\text { To examine the effects of } \\
\text { targeted early communication }\end{array}$ & $\begin{array}{l}\mathrm{n}=30 \text { adults } \\
\text { Mean age: } 60 \mathrm{yrs}\end{array}$ & Adult ICU & $\begin{array}{l}\text { Inclusion: Tracheostomy }>48 \text { hrs, mechanical ventilation, } \\
\text { FiO2 }<0.4 \text {, PEEP }<10 \mathrm{~cm} \mathrm{H} 2 \mathrm{O} \text {, awake \& obeying commands } \\
\text { Exclusions: bulbar palsy, unable to tolerate cuff deflation, } \\
\text { brainstem stroke, recent head and neck surgeries }\end{array}$ & $\begin{array}{l}\text { Time to phonation, duration of } \\
\text { tracheostomy cannulation (days), } \\
\text { duration of mechanical ventilation, } \\
\text { length of ICU \& hospital stay, time to } \\
\text { oral intake, quality of life (VASES \& EQ- } \\
\text { 5D) }\end{array}$ \\
\hline $\begin{array}{l}\text { Leder et al. } \\
(1999)^{[16]}\end{array}$ & $\begin{array}{l}\text { Prospective } \\
\text { Descriptive } \\
\text { Study }\end{array}$ & $\begin{array}{l}\text { To assess the incidence of } \\
\text { aspiration with and without SV }\end{array}$ & $\begin{array}{l}\mathrm{n}=20 \\
\text { 44-86 years } \\
\text { Mean age: } 67.8 \mathrm{yrs}\end{array}$ & $\begin{array}{l}\text { Large tertiary } \\
\text { teaching hospital }\end{array}$ & $\begin{array}{l}\text { Inclusion: tracheostomy tube; non ventilator-dependent, } \\
\text { documentation of aspiration by FEES, no prior use of SV, } \\
\text { ability to tolerate SV without oxygen desaturation, }>2 \text { days } \\
\text { use of SV with intelligent production, no motor speech } \\
\text { disorders, no surgery of upper aero-digestive tract (except } \\
\text { tracheostomy) }\end{array}$ & $\begin{array}{l}\text { Aspiration of liquid and pureed } \\
\text { consistencies (FEES) }\end{array}$ \\
\hline $\begin{array}{l}\text { Lichtman et al. } \\
(1995)^{[25]}\end{array}$ & $\begin{array}{l}\text { Prospective } \\
\text { Observational } \\
\text { Study }\end{array}$ & $\begin{array}{l}\text { To quantify if the use of SV will } \\
\text { result in decreased secretions, } \\
\text { increased arterial oxygenation } \\
\text { and increased olfaction }\end{array}$ & $\begin{array}{l}\mathrm{n}=8 \\
31-76 \text { years } \\
\text { Mean age: } 56.6 \mathrm{yrs}\end{array}$ & Tertiary Institution & $\begin{array}{l}\text { Inclusion: } \geq 18 \text { years, tolerate wearing SV }>3 \text { hours, able to } \\
\text { follow oral directions, no unstable medical, neurological or } \\
\text { cardiac conditions, no use of activase, streptokinase, } \\
\text { coumadin, warfarin or other thombolytic agents, able to } \\
\text { tolerate cuff deflation and blue dye swallow evaluation }\end{array}$ & $\begin{array}{l}24 \text { hour secretion accumulation }(\mathrm{mL}) ; \\
\mathrm{SpO} 2 ; \mathrm{pH}, \mathrm{PaCO} 2, \mathrm{PaO} 2, \mathrm{HCO} 3, \mathrm{SaO} 2 \\
\text { olfaction }\end{array}$ \\
\hline $\begin{array}{l}\text { Manzano et al. } \\
(1993)^{[22]}\end{array}$ & $\begin{array}{l}\text { Prospective } \\
\text { observational } \\
\text { study }\end{array}$ & $\begin{array}{l}\text { To assess whether } \\
\text { communication capabilities of } \\
\text { ventilator-dependent patients } \\
\text { are improved by the use of a } \\
\text { one way SV }\end{array}$ & $\begin{array}{l}\mathrm{n}=10 \\
20-67 \text { years } \\
\text { Mean age: } 56.3 \mathrm{yrs}\end{array}$ & $\begin{array}{l}\text { University Hospital, } \\
\text { ICU }\end{array}$ & $\begin{array}{l}\text { Inclusion: ability to eliminate secretions and maintain an } \\
\text { unobstructed airway, adequate gas exchange while } \\
\text { ventilated with an FiO2 of } \leq 0.4, \mathrm{PaCO} 2 \text { of } \leq 55 \text { torr, normal } \\
\text { haemodynamics without the need for vasopressors, and } \\
\text { normal mental state }\end{array}$ & $\begin{array}{l}\text { Communication; RR; PaCO2; PaO2; HR; } \\
\text { SBP; sense of well-being; tracheal } \\
\text { secretion; olfaction }\end{array}$ \\
\hline $\begin{array}{l}\text { Ongkasuwan et } \\
\text { al. }(2014)^{[19]}\end{array}$ & $\begin{array}{l}\text { Prospective } \\
\text { Case-control } \\
\text { study }\end{array}$ & $\begin{array}{l}\text { To determine if SV decreases } \\
\text { laryngeal penetration and } \\
\text { aspiration in tracheostomised } \\
\text { children }\end{array}$ & $\begin{array}{l}n=12 \\
3 \text { months }-9 \text { years } \\
\text { Mean age: } 2.2 \text { yrs }\end{array}$ & Not documented & Inclusion: able to tolerate SV & $\begin{array}{l}\text { Aspiration of thin and pureed } \\
\text { consistencies during a modified barium } \\
\text { swallow, graded on an 8-point } \\
\text { Penetration-Aspiration Scale }\end{array}$ \\
\hline $\begin{array}{l}\text { Passy et al. } \\
(1993)^{[23]}\end{array}$ & $\begin{array}{l}\text { Prospective } \\
\text { Study }\end{array}$ & $\begin{array}{l}\text { To assess the effectiveness of } \\
\text { speech with one way SV in } \\
\text { ventilator-dependent patients }\end{array}$ & $\begin{array}{l}n=15 \\
6 \text { to } 65 \text { years } \\
\text { Mean age: } 35.0 \text { yrs }\end{array}$ & Not documented & $\begin{array}{l}\text { Inclusion: ventilator-dependent patients, using SV for }>4 \\
\text { hours per day } \\
\text { Exclusion: severe acute patients requiring } 24 \text { hours assisted } \\
\text { control ventilation with cuffed tracheostomy tubes }\end{array}$ & $\begin{array}{l}\text { Speech/ communication (subjectively } \\
\text { assessed); tracheal secretions; } \\
\text { emotional status; olfaction; } \mathrm{SpO} 2\end{array}$ \\
\hline
\end{tabular}




\begin{tabular}{|c|c|c|c|c|c|c|}
\hline $\begin{array}{l}\text { Prigent et al. } \\
\text { (2012) } \\
{[28]}\end{array}$ & $\begin{array}{l}\text { Prospective } \\
\text { Observational } \\
\text { Study }\end{array}$ & $\begin{array}{l}\text { To assess upper airways and } \\
\text { tracheostomy tube flows } \\
\text { during swallowing and the } \\
\text { breathing-swallowing } \\
\text { interactions with and without a } \\
\text { SV }\end{array}$ & $\begin{array}{l}\mathrm{n}=8 \\
29-62 \text { years } \\
\text { Mean age: } 44.3 \mathrm{yrs}\end{array}$ & $\begin{array}{l}\text { Outpatients from } \\
\text { home ventilation } \\
\text { service }\end{array}$ & $\begin{array}{l}\text { Inclusion: tracheostomy with cuffless tube for }>6 \text { months, } \\
\text { used a SV, ate without ventilation assistance, clinically stable }\end{array}$ & $\begin{array}{l}\text { Tracheal and nasal airflow } \\
\text { (pneumotachograph); and tracheal } \\
\text { pressure (pressure transducer); } \\
\text { Swallowing function including: duration } \\
\text { of swallow (sec); number of swallows } \\
\text { per bolus; number of ventilator cycles } \\
\text { per bolus; percentage of swallows } \\
\text { followed by expiration }\end{array}$ \\
\hline $\begin{array}{l}\text { Srinet et al. } \\
(2015)^{[15]}\end{array}$ & $\begin{array}{l}\text { Prospective } \\
\text { consecutive } \\
\text { cohort study }\end{array}$ & $\begin{array}{l}\text { To investigate the } \\
\text { biomechanical effect SV on } \\
\text { movement of the hyoid bone } \\
\text { and larynx during swallowing }\end{array}$ & $\begin{array}{l}\mathrm{n}=10 \\
61-89 \text { years } \\
\text { Mean age: } 71.2 \mathrm{yrs}\end{array}$ & Not documented & $\begin{array}{l}\text { Inclusion: } \geq 18 \text { years, English speaking, ability to tolerate } \\
\text { changing to a Blom tracheostomy tube and tolerating a SV } \\
\text { with a fully deflated cuff }\end{array}$ & $\begin{array}{l}\text { Larynx to hyoid bone excursion during } \\
\text { swallowing (VFSS) }\end{array}$ \\
\hline $\begin{array}{l}\text { Stachler et al. } \\
(1996)^{[17]}\end{array}$ & $\begin{array}{l}\text { Prospective } \\
\text { Study }\end{array}$ & $\begin{array}{l}\text { To assess the presence and } \\
\text { amount of aspirate with and } \\
\text { without a SV in place }\end{array}$ & $\begin{array}{l}\mathrm{n}=11 \\
\text { Mean age: } \text { unable to } \\
\text { be calculated }\end{array}$ & Not documented & $\begin{array}{l}\text { Inclusion: tracheostomised patients suspected for aspiration, } \\
\text { tolerate a plugged tracheostomy tube for short periods }\end{array}$ & Aspiration (VFSS) \\
\hline $\begin{array}{l}\text { Suiter et al. } \\
(2003)^{[13]}\end{array}$ & $\begin{array}{l}\text { Prospective } \\
\text { Study }\end{array}$ & $\begin{array}{l}\text { To assess the effects of SV on } \\
\text { aspiration and swallow } \\
\text { physiology }\end{array}$ & $\begin{array}{l}\mathrm{n}=18 \\
19-80 \text { years } \\
\text { Mean age: unable to } \\
\text { be calculated }\end{array}$ & Acute care hospital & $\begin{array}{l}\text { Inclusion: non-ventilator dependence, ability to tolerate cuff } \\
\text { deflation during VFSS, no surgery to upper aerodigestive } \\
\text { tract except for tracheostomy, no history of oropharyngeal } \\
\text { cancer or stroke, at least occasion of aspiration on thin liquid } \\
\text { or puree }\end{array}$ & $\begin{array}{l}\text { Aspiration (8-point penetration- } \\
\text { aspiration scale); swallow duration } \\
\text { (sec); hyolaryngeal excursion ( } \mathrm{mm} \text { ); } \\
\text { residue }\end{array}$ \\
\hline $\begin{array}{l}\text { Sutt et al. } \\
(2015)^{[10]}\end{array}$ & $\begin{array}{l}\text { Retrospective } \\
\text { audit }\end{array}$ & $\begin{array}{l}\text { To assess the effect of the } \\
\text { introduction of in-line } \\
\text { tracheostomy SV on the } \\
\text { duration of mechanical } \\
\text { ventilation }\end{array}$ & $\begin{array}{l}\mathrm{n}=56 \text { pre- } \\
\text { implementation, } \\
\text { Mean age: } 58.5 \mathrm{yrs} \\
\mathrm{n}=73 \text { post } \\
\text { implementation } \\
\text { Mean age: } 59.0 \mathrm{yrs}\end{array}$ & Cardiothoracic ICU & Inclusion: all tracheostomised patients in a 2-year period & $\begin{array}{l}\text { Duration of MV (days); ETT duration } \\
\text { (days); TT duration (days); TT insertion } \\
\text { to SV (days); SV to decannulation } \\
\text { (days); TT to first oral intake (days) }\end{array}$ \\
\hline $\begin{array}{l}\text { Sutt, et al. } \\
(2016)[24]\end{array}$ & $\begin{array}{l}\text { Prospective } \\
\text { Observational } \\
\text { Study }\end{array}$ & $\begin{array}{l}\text { To assess end expiratory lung } \\
\text { impedance with use of SV }\end{array}$ & $\begin{array}{l}n=20 \\
\text { Mean age: } 60 \text { years }\end{array}$ & Cardiothoracic ICU & $\begin{array}{l}\text { Inclusion: tolerated SV for }>30 \text { mins, mechanically ventilated } \\
\text { or spontaneously ventilating } \\
\text { Exclusion: significant language or cognitive deficits, not } \\
\text { suitable to wear an EIT belt }\end{array}$ & $\begin{array}{l}\text { End expiratory lung impedance (EIT- } \\
\text { lectrical impedance tomography), HR, } \\
\mathrm{RR}, \mathrm{EtCO} 2, \mathrm{SpO} 2\end{array}$ \\
\hline $\begin{array}{l}\text { Sutt et al. } \\
(2017)^{[27]}\end{array}$ & $\begin{array}{l}\text { Prospective } \\
\text { Observational } \\
\text { Study }\end{array}$ & $\begin{array}{l}\text { To determine changes in } \\
\text { ventilation distribution with } \\
\text { use of SV }\end{array}$ & $\begin{array}{l}n=20 \\
\text { Mean age: } 60 \text { years }\end{array}$ & Cardiothoracic ICU & $\begin{array}{l}\text { Inclusion: tolerated SV for }>30 \text { mins, mechanically ventilated } \\
\text { or spontaneously ventilating } \\
\text { Exclusion: significant language or cognitive deficits, not } \\
\text { suitable to wear an EIT belt }\end{array}$ & $\begin{array}{l}\text { EELI distribution and tidal variation } \\
\text { (TV), alveolar recruitment (VSA- } \\
\text { ventilated surface area \& RVD- regional } \\
\text { ventilation delay) }\end{array}$ \\
\hline
\end{tabular}

\section{Abbreviations:}

SV - speaking valve; HR - heart rate; RR- respiratory rate; $\mathrm{PaO2}$ - partial pressure of oxygen; PaCO2 - partial pressure of carbon dioxide; EtCO2 - end tidal carbon dioxide; SpO2- peripheral oxygen saturations; FEES fiberoptic endoscopic evaluation of swallowing; SaO2 - arterial oxygen saturations; FiO2 - fraction of inspired oxygen; HCO3- - bicarbonate; TT - tracheostomy tube; VFSS - videofluroscopic study of swallowing; MV mechanical ventilation; ICU - intensive care unit: 
Table 3: Results from Included Studies

\begin{tabular}{|c|c|c|c|}
\hline Authors & Results & Conclusion & Favours \\
\hline $\begin{array}{l}\text { Barraza et al. } \\
(2014)^{[21]}\end{array}$ & $\begin{array}{l}\text { No significant differences occurred in } \mathrm{RR}, \mathrm{HR}, \mathrm{SpO} 2 \\
\text { or EtCO2 with speaking valve in situ while asleep } \\
\text { No adverse events occurred while sleeping with } \\
\text { speaking valve in situ }\end{array}$ & $\begin{array}{l}\text { Speaking valves can be safely used during } \\
\text { sleep in children with tracheostomy tubes. }\end{array}$ & $\begin{array}{l}\text { Not Statistically } \\
\text { Significant }\end{array}$ \\
\hline $\begin{array}{l}\text { Dettelbach et al. } \\
(1995)^{[12]}\end{array}$ & $\begin{array}{l}\text { Aspiration of all consistencies was reduced when } \\
\text { participants had speaking valve in situ }\end{array}$ & $\begin{array}{l}\text { Speaking valves reduces, or eliminates } \\
\text { aspiration in patients with tracheostomies }\end{array}$ & Intervention Group \\
\hline $\begin{array}{l}\text { Elpern et al. } \\
(2000)^{[14]}\end{array}$ & $\begin{array}{l}\text { Aspiration was significantly reduced with speaking } \\
\text { valve in situ ( } 6.9 \% \text { vs } 29.5 \%) P=0.016\end{array}$ & $\begin{array}{l}\text { The speaking valve is a simple inexpensive } \\
\text { option to reduce aspiration in patients with } \\
\text { tracheostomies. }\end{array}$ & Intervention Group \\
\hline $\begin{array}{l}\text { Freeman- } \\
\text { Sanderson et al. } \\
(2016)^{[26]}\end{array}$ & $\begin{array}{l}\text { Speaking valves significantly hastened return to } \\
\text { phonation (median difference } 11 \text { days, } p=0.001 \text { ), } \\
\text { no difference in decannulation time, mechanical } \\
\text { ventilation time, length of stay, or time to oral } \\
\text { intake, adverse events, or quality of life }\end{array}$ & $\begin{array}{l}\text { Speaking valves hastens return to phonation } \\
\text { in mechanically ventilated patients }\end{array}$ & Intervention Group \\
\hline $\begin{array}{l}\text { Leder et al. } \\
(1999)^{[16]}\end{array}$ & $\begin{array}{l}\text { Aspiration was eliminated in seven out of } 20 \\
\text { patients with use of speaking valve ranging from 2- } \\
7 \text { days }\end{array}$ & $\begin{array}{l}\text { Speaking valves reduced aspiration in some } \\
\text { patients, but no difference in the length of } \\
\text { time with speaking valve use }\end{array}$ & Intervention Group \\
\hline $\begin{array}{l}\text { Lichtman et al. } \\
(1995)^{[25]}\end{array}$ & $\begin{array}{l}\text { While wearing the speaking valve, patients } \\
\text { accumulated fewer secretions }(74.3+/-63.6 \mathrm{~mL} \text { vs } \\
122.8+/-44.6 \mathrm{~mL}) \text { and improved olfaction } \\
\text { accuracy }(28.4+/-5.2 \text { vs } 8.1+/-2.9 \%) \text {. There was } \\
\text { no significant difference in oxygen saturation and } \\
\text { arterial blood gases with and without the speaking } \\
\text { valve }\end{array}$ & $\begin{array}{l}\text { Speaking valves demonstrate significant } \\
\text { secondary benefits, including a decrease in } \\
\text { total secretions accumulated and improved } \\
\text { olfaction. }\end{array}$ & Intervention Group \\
\hline $\begin{array}{l}\text { Manzano et al. } \\
(1993)^{[22]}\end{array}$ & $\begin{array}{l}\text { The speaking valve was effective in improving } \\
\text { communication in } 8 \text { out of } 10 \text { participants. } \\
\text { Cardiorespiratory changes were insignificant; but } \\
\text { there was subjective improvement in well-being, } \\
\text { and reduction in secretions. }\end{array}$ & $\begin{array}{l}\text { The speaking valve allows ventilator- } \\
\text { dependent patients to talk and communicate } \\
\text { without assistance. Participants had improved } \\
\text { well-being and were motivated to participate } \\
\text { in their own cares. }\end{array}$ & Intervention Group \\
\hline $\begin{array}{l}\text { Ongkasuwan et al. } \\
(2014)^{[19]}\end{array}$ & $\begin{array}{l}\text { Laryngeal aspiration and penetration was reduced } \\
\text { in pureed consistencies compared with thin liquid, } \\
\text { but there was no difference with or without the } \\
\text { speaking valve. There was a decrease in piriform } \\
\text { sinus residue with the presence of the speaking } \\
\text { valve. }\end{array}$ & $\begin{array}{l}\text { Speaking valves did not decrease laryngeal } \\
\text { aspiration or penetration in children with } \\
\text { tracheostomies, but did improve piriform } \\
\text { sinus residue. }\end{array}$ & $\begin{array}{l}\text { Not statistically } \\
\text { significant }\end{array}$ \\
\hline $\begin{array}{l}\text { Passy et al. } \\
(1993)^{[23]}\end{array}$ & $\begin{array}{l}\text { All patients had a subjective improvement in } \\
\text { speech, including improvements in intelligibility, } \\
\text { volume, and quality. Nursing staff also reported } \\
\text { that patient had a decreased need for suctioning, } \\
\text { and } 9 \text { out of } 15 \text { reported improvements in energy } \\
\text { levels. } 14 \text { out of } 15 \text { also had improvements in } \\
\text { olfaction with the speaking valve in place. There } \\
\text { was no significant difference in oxygen saturations } \\
\text { with or without the speaking valve. }\end{array}$ & $\begin{array}{l}\text { The speaking valve is a safe adjunct to } \\
\text { improving communication in ventilator- } \\
\text { dependent patients. Improvements in the } \\
\text { patients energy levels and emotional state, in } \\
\text { additional to a decrease in oral and nasal } \\
\text { secretions, has given patients a feeling of } \\
\text { independence resulting in improved physical } \\
\text { and mental health, improved dietary intake, } \\
\text { and a better outlook on life. }\end{array}$ & Intervention Group \\
\hline $\begin{array}{l}\text { Prigent et al. (2012) } \\
\text { [28] }\end{array}$ & $\begin{array}{l}\text { Without the speaking valve a significant part of the } \\
\text { expiratory flow leaked through the tracheostomy } \\
\text { tube. The speaking valve increased the expired } \\
\text { volume through the upper airways after } \\
\text { swallowing, which was negligible without the } \\
\text { speaking valve. The duration of swallowing, } \\
\text { number of swallows and number of ventilator } \\
\text { cycles did not differ with or without the speaking } \\
\text { valve. }\end{array}$ & $\begin{array}{l}\text { The use of a speaking valve should be offered } \\
\text { routinely during periods off mechanical } \\
\text { ventilation to facilitate expiration through the } \\
\text { upper airways after swallowing and to } \\
\text { decreased the risk of aspiration or laryngeal } \\
\text { penetration }\end{array}$ & Intervention Group \\
\hline $\begin{array}{l}\text { Srinet et al. } \\
(2015)^{[15]}\end{array}$ & $\begin{array}{l}\text { No difference was found for laryngeal excursion or } \\
\text { hyoid bone displacement during swallowing with } \\
\text { or without a speaking valve. } \\
\text { Aspiration status was also unchanged by use of } \\
\text { speaking valve. }\end{array}$ & $\begin{array}{l}\text { These results do not support the placement of } \\
\text { a one-way speaking valve to reduce prandial } \\
\text { aspiration }\end{array}$ & $\begin{array}{l}\text { Not statistically } \\
\text { significant }\end{array}$ \\
\hline $\begin{array}{l}\text { Stachler et al. } \\
(1996)^{[17]}\end{array}$ & $\begin{array}{l}\text { Patients aspirated significantly less with the } \\
\text { speaking valve on, than with the tracheostomy } \\
\text { open. }\end{array}$ & $\begin{array}{l}\text { Speaking valve may help keep patients in the } \\
\text { best physical, nutritional and respiratory } \\
\text { status possible. The use of a speaking valve } \\
\text { could facilitate earlier enteral feeding with a } \\
\text { smaller risk of aspiration. }\end{array}$ & Intervention Group \\
\hline $\begin{array}{l}\text { Suiter et al. } \\
(2003)^{[13]}\end{array}$ & $\begin{array}{l}\text { Cuff inflated vs deflated had no effect on } \\
\text { penetration or aspiration. Speaking valves } \\
\text { significantly reduced scores on the penetration- } \\
\text { aspiration scale for liquid bolus. }\end{array}$ & $\begin{array}{l}\text { Patients who are able to tolerate cuff } \\
\text { deflation and speaking valves, may benefit } \\
\text { from eating with a speaking valve in place. } \\
\text { Tracheostomised patients who are unable to } \\
\text { tolerate thin liquids may be able to safely take } \\
\text { thin liquids when a speaking valve in place. }\end{array}$ & Intervention Group \\
\hline Sutt et al. $(2015)^{[10]}$ & In-line speaking valves did not negatively impact & The use of in-line speaking valves allow verbal & Intervention Group \\
\hline
\end{tabular}




\begin{tabular}{|c|c|c|c|}
\hline & $\begin{array}{l}\text { on duration of mechanical ventilation and led to a } \\
\text { significant increase in time where verbal } \\
\text { communication was possible. There was no } \\
\text { significant difference in time to first oral intake, } \\
\text { however modification of fluids was less frequent } \\
\text { following the introduction of in-line speaking } \\
\text { valves. }\end{array}$ & $\begin{array}{l}\text { communication sooner and improved oral } \\
\text { intake, with no adverse effect on ventilation } \\
\text { times. }\end{array}$ & \\
\hline $\begin{array}{l}\text { Sutt, et al. } \\
(2016)[24]\end{array}$ & $\begin{array}{l}\text { Speaking valves result in significant increase of } \\
\text { EELI (mean increase by } 83.6 \% \text { from baseline, } p \\
<0.001 \text { ). EtCO2 and RR significantly decreased with } \\
\text { speaking valve in situ. No change to } \mathrm{SpO} 2 \text {. }\end{array}$ & $\begin{array}{l}\text { Speaking valves do not cause derecruitment of } \\
\text { the lungs. Speaking valves may facilitate lung } \\
\text { recruitment during and after use }\end{array}$ & Intervention Group \\
\hline Sutt et al. $(2017)^{[27]}$ & $\begin{array}{l}\text { Use of speaking valves result in increases in EELI } \\
\text { uniform across all lung sections ( } p<0.001), \text { TV } \\
\text { significantly improved above baseline }(p<0.001) \text {. } \\
\text { No significant changes to VSA \& RVD. }\end{array}$ & $\begin{array}{l}\text { The use of a speaking valve does not lead to } \\
\text { hyperinflation }\end{array}$ & Intervention Group \\
\hline
\end{tabular}

\section{Discussion}

Whilst the one-way speaking valve was initially developed in 1985 to enable speech and enhance communication, further studies have since assessed its benefits across various physiological and clinical domains. As such, this systematic review is the first to formally assess these additional benefits of using a speaking valve in terms of outcome measures such as swallowing and aspiration, secretion management, physiological measures, olfaction, weaning, ventilation, ICU and hospital length of stay, and quality of life. Although there were disparities in reported benefits in the literature, the most notable outcomes were in the domains of swallowing and aspiration where the use of a speaking valve reduced aspiration in tracheostomised patients (Figure 2).

Other notable outcomes were the significant improvements in EELI, an indication of ventilation [24, 27]. This suggests an improvement in ventilation by up to $120 \%$ from baseline following 30 minutes of using a speaking valve, and furthermore the presence of speaking valve did not cause derecruitment or over-distention [24, 27], a previous concern in the literature.

A number of limitations were identified in this review, including the small number of studies, low subject numbers, and heterogeneous populations. Heterogeneity is often observed in systematic reviews, and this was evident for this investigated topic. In this report, heterogeneity was related to baseline characteristics of the subjects, including age, primary diagnosis, and length of time with tracheostomy prior to use of a speaking valve, and each of these factors can greatly affect the outcomes under investigation due to physiological changes that occur with aging, underlying swallow pathology, and the altered anatomy, disuse and desensitization that occurs with the presence of a tracheostomy [28]. Although speaking valves are widely used in ICUs worldwide, these are only suitable for small percentage of ICU patients. Hence, it is difficult to gain strong evidence to support its full utility unless large multicenter randomized trials are conducted.

From a clinical perspective, many patients utilise a speaking valve primarily to enhance speech and communication, but may in fact be improving other physiological and clinical parameters. Whilst the evidence to date is not strong to support these, all the studies favored the intervention group or reported improvements that were not statistically significant. None of the studies reported negative clinical outcomes when subjects were using a speaking valve, suggesting that along with the potential psychological benefits of using a speaking valve, they may provide improvements in other clinical areas. Additionally, if the evaluation of the benefits for speaking valves were focused on the additional utilities rather than just communication, this may help build a stronger evidence base.

It should also be noted that although very few adverse outcomes were reported, the definition of an adverse event was not well defined in any of the studies. An example of this is the study in which 
two subjects experienced large decreases in their HR while using a speaking valve [22]. This was not reported as an adverse event despite their recorded HR being well below the normal range. Another study [23] reported that 9 out of 15 participants required an increase in their tidal volume, and 7 out of 15 participants required an increase in their inspiratory pressure on the ventilator settings to maintain adequate oxygenation when using the speaking valve, and that all participants required a $>50 \%$ increase in inspiratory volume to maintain peak inflation pressure [22]. These changes were considered within normal practice for use of a speaking valve; however, some may consider these adverse events necessitating major ventilator changes to maintain optimal clinical status.

Another limitation of this review is the limited ability to generalise the study results to a range of clinical patients. An example of this is the assessment of safety with speaking valves during sleep. It has previously been recommended that speaking valves should only been used while patients are awake as they may cause increased work of breathing trying to exhale around the tracheostomy tube. Only one study [21] assessed safety with speaking valves during sleep, and although there were no adverse events, the study only assessed children less than 9 years of age, with a stable clinical status, and during one 8-hour period of sleep. This study also did not collect data on the quality of sleep, and although the results from this study reported that speaking valves appeared to be safe during sleep in this specific clinical group, it cannot be recommended that speaking valves are safe for use while sleeping across all populations.

Future studies should therefore address the limitations of the current literature. In addition, the overall well-being of patients with speaking valves has not been adequately assessed. It is hypothesised that with improved communication, the patients' overall well-being would also improve. Although there were reported improvements in the participants well-being [22, 23], this was only subjectively commented on by either nursing staff or the patient, and not quantified in any quality of life outcome measures. The only study to comment on objective improvements in quality of life [26] favoured the intervention group across the domains on the VASES and the EQ-5D. Studies relating to overall physiological improvements which result in reduced ICU and hospital length of stay and/or a reduction in overall healthcare costs would be of interest to stakeholders. However, this has not yet been widely examined in the literature. Length of stay was only investigated in one study [26], and whilst it did address both quality of life and length of stay outcomes, the study was underpowered with a small sample of only 15 participants and not statistically significant.

\section{Conclusion}

The results were not statistically significant for the majority of outcome measures including physiological measures, weaning, quality of life, and length of stay. However, statistically significant results were found for improvements in ventilation and ventilation distribution, olfaction and secretion management. A meta-analysis was only possible for comparing aspiration across five studies, and this remains the only outcome with a statistically significant result. Further studies evaluating physiological and clinical outcomes with the use of a speaking valve could provide a strong evidence base for implementation in a variety of clinical settings, particularly across the domains of ventilator and tracheostomy weaning, ventilation, and ICU and hospital length of stay which have to potential to reduce healthcare costs. 


\section{References}

1. Durbin CG. Tracheostomy: why, when and how? Respiratory Care, 2010; 55(8): p. 1056-68.

2. Vargas $M$, Servillo $G$, Arditi E, et al. Tracheostomy in Intensive Care Unit: a nationl survey in Italy. Minerva Anestesiologica, 2013; 79(2): p. 156-64.

3. Lichtman SW, Birnbaum IL, Sanfilippo MR, et al. Effect of a tracheostomy speak valve on secretions, arterial oxygenation, and olfaction: a quantitative evaluation. Journal of Speech and Hearing Research, 1995; 38(3): p. 549-55.

4. Passy-Muir Inc. What is a Passy-Muir valve? 2013 20/2/13]; Available from: http://www.passy-muir.com/what_is.

5. Eibling DE and Gross RD. Subglottic air pressure: a key component of swallowing efficiency. Annals of Otology, Rhinology and Laryngology, 1996; 105(4): p. 253-9.

6. Gurnari D and Martin C. Early collaboration of respiratory and rehabilitation department improves ventilator weaning rates. in 22nd Annual Meeting of the National Association of Long Term Care Hospital. 2011. Washington D. C.

7. Vargas M, Sutherasan Y, Gregoretti C, et al. PEEP Role in ICU and Operating Room: From Pathophysiology to Clinical Practice. The Scientific World Journal, 2014; 2014: p. 8.

8. Edmonton AB, Quality Appraisal of Case Series Studies Checklist. 2014, Institute of Health Economics (IHE).

9. Guo B, Moga C, Harstall C, et al. A principal component analysis is conducted for a case series quality appraisal checklist. Journal of Clinical Epidemiology, 2016; 69: p. 199-207.e2.

10. Sutt AL, Cornwell P, Mullany D, et al. The use of tracheostomy speaking valves in mechanically ventilated patients results in improved communication and does not prolong ventilation time in cardiothoracic intensive care unit patients. Journal of critical care, 2015; 30(3): p. 491-4.

11. Biostat., Comprehensive Meta-Anaylsis Version 2 [software]. Available at: http://www.metaanalysis.com.

12. Dettelbach MA, Gross RD, Mahlmann J, et al. Effect of the Passy-Muir Valve on aspiration in patients with tracheostomy. Head \& Neck, 1995; 17(4): p. 297-302.

13. Suiter DM, McCullough GH, and Powell PW. Effects of cuff deflation and one-way tracheostomy speaking valve placement on swallow physiology. Dysphagia, 2003; 18(4): p. 284-92.

14. Elpern EH, Okonek MB, Bacon M, et al. Effect of the Passy-Muir tracheostomy speaking valve on pulmonary aspiration in adults. Heart \& Lung: The Journal of Acute and Critical Care, 2000; 29(4): p. 287-93.

15. Srinet P, Van Daele DJ, Adam SI, et al. A Biomechanical Study of Hyoid Bone and Laryngeal Movements During Swallowing Comparing the Blom Low Profile Voice Inner Cannula and Passy-Muir One Way Tracheotomy Tube Speaking Valves. Dysphagia, 2015; 30(6): p. 723-9.

16. Leder SB. Effect of a one-way tracheotomy speaking valve on the incidence of aspiration in previously aspirating patients with tracheotomy. Dysphagia, 1999; 14(2): p. 73-7.

17. Stachler RJ, Hamlet SL, Choi J, et al. Scintigraphic Quantification of Aspiration Reduction With the Passy-Muir Valve. The Laryngoscope, 1996; 106(2): p. 231-4.

18. Prigent $\mathrm{H}$, Lejaille $\mathrm{M}$, Terzi $\mathrm{N}$, et al. Effect of tracheostomy speaking valve on breathingswallowing interaction. Intensive Care Medicine, 2012; 38(1): p. 85-90.

19. Ongkasuwan J, Turk CL, Rappazzo CA, et al. The effect of a speaking valve on laryngeal aspiration and penetration in children with tracheotomies. The Laryngoscope, 2014; 124(6): p. 1469-74. 
20. Leder SB. Perceptual rankings of speech quality produced with one-way tracheostomy speaking valves. Journal of Speech, Language, and Hearing Research, 1994; 37(6): p. 130812.

21. Barraza GY, Fernandez C, Halaby C, et al. The safety of tracheostomy speaking valve use during sleep in children: a pilot study. American journal of otolaryngology, 2014; 35(5): p. 636-40.

22. Manzano JL, Lubillo S, Henríquez D, et al. Verbal communication of ventilator-dependent patients. Critical care medicine, 1993; 21(4): p. 512-7.

23. Passy V, Baydur A, Prentice $W$, et al. Passy-Muir tracheostomy speaking valve on ventilatordependent patients. The Laryngoscope, 1993; 103(6): p. 653-8.

24. Sutt AL, Caruana LR, Dunster KR, et al. Speaking valves in tracheostomised ICU patients weaning off mechanical ventilation - do they facilitate lung recruitment? Journal of Critical Care, 2016; 20(91).

25. Lichtman SW, Birnbaum IL, Sanfilippo MR, et al. Effect of a tracheostomy speaking valve on secretions, arterial oxygenation, and olfaction: a quantitative evaluation. Journal of speech and hearing research, 1995; 38(3): p. 549-55.

26. Freeman - Sanderson AL, Togher L, Elkins MR, et al. Return of voice for ventilated tracheostomy patients in ICU: a randomised controlled trial of early-targeted intervention. Critical Care Medicine, 2016; 44: p. 1075-81.

27. Sutt AL, Anstey CM, Caruana LR, et al. Ventilation distribution and lung recruitment with speaking valve use in tracheostomised patient weaning from mechanical ventilation in intensive care. Journal of Critical Care, 2017; 40: p. 164-70.

28. Prigent $\mathrm{H}$, Lejaille $\mathrm{M}$, Terzi $\mathrm{N}$, et al. Effect of a tracheostomy speaking valve on breathingswallowing interaction. Intensive care medicine, 2012; 38(1): p. 85-90. 